\title{
Selection of allozyme genotypes of two species of marine gastropods (genus Littorina) in experiments of environmental stress by nonionic detergent and crude oil-surfactant mixtures
}

\author{
E. Nevo and B. Lavie
}

University of Haifa, Institute of Evolution, Mt Carmel, Haifa, Israel

(received 25 January 1989, accepted 5 May 1989)

Summary - Two marine gastropods, Littorina punctata and L. neritoides were exposed in laboratory experiments to the controlled environmental stress of pollution by detergent and by crude oil-detergent mixtures in aqueous solutions. The allozyme frequencies of phosphoglucose isomerase ( $P G I)$ were tested in both species and amino-peptidase $(A P)$ only in $L$. neritoides. Our results indicate differential survivorship of allozyme genotypes for both species, both types of pollution and both enzymes observed. These results indicate the sensitivity of allozymes to environmental stress, reflect the adaptive nature of some allozymes, and support the idea that allozymes could be used as detectors of organic pollutants in the sea.

selection - organic pollution - allozyme polymorphism - marine gastropod

Résumé - Sélection de génotypes allozymes chez deux espèces de gastéropodes marins (genre Littorina) dans des expériences de stress environnemental par un détergent non ionique et par ses mélanges avec des huiles brutes. Deux gastéropodes marins, Littorina punctata et L. neritoides, ont été exposés en laboratoire des stress environnementaux correspondant à une pollution par un détergent et par ses mélanges avec des huiles brutes en solutions acqueuses. Les fréquences des allozymes de la phosphoglucose-isomérase (PGI) ont été testées chez les deux espèces, et celles de l'amino-peptidase (AP) chez L. neritoides seulement. Les résultats indiquent une survivance différentielle des différents génotypes, pour les deux espèces, pour les deux types de pollution, et pour les deux enzymes étudiées. Ces résultats indiquent que les allozymes sont sensibles à des stress de l'environnement, ils reflètent la nature adaptative de certains allozymes, et renforcent l'idée que des allozymes puissent être utilisés pour détecter des polluants organiques dans la mer.

sélection - pollution organique - polymorphisme enzymatique - gastéropode marin

\section{INTRODUCTION}

The evolutionary significance and dynamics of the vast amount of protein polymorphisms in nature, and the relative importance of the deterministic and stochastic forces operating to maintain them, awaits additional critical testing. If 
this variation is largely adaptive, then it is exploitable in breeding (Nevo et al., 1982, Nevo 1986), meaningful in conservation (Frankel \& Soule, 1981; Schonewald-Cox et al., 1983; Soule, 1987), and exploitable as a detector and monitor of environmental quality (Nevo 1986, Nevo et al., 1983).

In the present study, we tested, in controlled laboratory experiments, the influence of a nonionic detergent and of crude oil-detergent mixtures in aqueous solutions on allozymic variation in the related species of marine gastropods Littorina punctata and $L$. neritoides. Their genetic structure, based on 17 loci in three Mediterranean sites along the Israel coast was described by Noy et al. (1987). Of the 17 loci tested, only phosphoglucose isomerase (PGI) for both species and amino peptidase (AP) for $L$. neritoides were found suitable for pollution investigations, which depend on the following stringent criteria:

- Loci tested for pollution must be strongly polymorphic $(>10 \%)$ in order to detect differential mortality in sample sizes involving several hundreds of animals.

- The enzyme tested must also remain active in the dead animals so that the distribution of genotypes can be compared directly between dead and live animals. Thus, no sampling error is added that would bias the results.

- A high resolution is imperative when scoring the electrophoretic results, because the difference in allozymic frequencies between live and dead animals may be small.

Our results indicate differential tolerance of allozymes to both pollutants tested, as was found in our previous studies (reviewed in Nevo, 1986), implying that at least some of the genetic diversity found in natural populations may be exploitable in the service of man as a genetic monitor of marine pollution.

\section{MATERIAL AND METHODS}

\section{Species tested and experimental design}

The present study involves two related marine mollusc species: Littorina punctata (Gemelin) and $L$. neritoides (L.) whose ecology in Israel was studied by Palant \& Fishelson (1968). Several hundreds of individuals from each species were collected from the rocky shores of the Haifa region and introduced in batches of 50-100 individuals into partially filled $80 \mathrm{~L}$ aquaria $(70 \times 30 \times 40 \mathrm{~cm})$ at the Institute of Evolution, University of Haifa, Israel. Fresh sea water was pumped from a $30 \mathrm{~m}$ depth at the Shikmona National Institute of Oceanography and transported to the laboratory. The two Littorina species tend to crawl on the aquaria walls, above the water level. To avoid this, they were placed in quadrangular cages $(25 \times 25 \times 5 \mathrm{~cm})$ made of perspex. These cages were subdivided into smaller interconnected cells $(5 \times 5 \times 5 \mathrm{~cm})$ by a plastic net so that water currents could pass freely through all cells. Each cell held two animals. Conditions in all aquaria were identical $\left(22^{\circ} \mathrm{C}\right.$, $\mathrm{pH}=8.1$; constant aeration and no food was provided throughout testing). All tests were conducted simultaneously and were matched with a control. Survival in the controls was always $100 \%$. The experimental organisms were observed daily; dead animals were removed and frozen $\left(-80^{\circ} \mathrm{C}\right)$. When mortality reached $50 \%\left(\mathrm{LD}_{50}\right)$, the test was terminated and all survivors were frozen $\left(-80^{\circ} \mathrm{C}\right)$. The duration of the test (2-10 days) varied, depending upon the concentrations of pollutants (Tables I, II). Similar trends have been observed in all concentrations, therefore the results were pooled. 


\section{The pollutants}

The nonionic detergent used was the commercially available Marlophen 89 (Hulls, West Germany). This product is a nonylphenol ethoxylate having an approximate molecular weight of 643 , the molar ratio between the ethylene oxide and the nonylphenol being 9.55:1 respectively. This nonionic detergent is of the "hard" type, that is, resistant to biological degradation. The crude oil used ("Sonol 2", obtained from the Israeli Oil Refineries Ltd, in Haifa), had the following specifications: density at $15{ }^{\circ} \mathrm{C}: 0.9152$. Distillation Range (\% wt): to $150^{\circ} \mathrm{C}, 8.3 \%$; $150-250{ }^{\circ} \mathrm{C}, 17.7 \% ; 250-400{ }^{\circ} \mathrm{C}, 21.2 \%$; Res. > 400, 51.9\%. Kinematic Viscosity: at $122 \mathrm{f}, 15.8 \mathrm{cP}$. Total Sulfur (\% wt): 1.4. Salt PTB: 11. Water (\% V): 0.05. Carbon Residue (\% wt): 5.3; Asphaltenes (\% wt): 0.8 .

\section{Electrophoretic analysis}

For the electrophoretic analysis, whole frozen animals were homogenized and studied by horizontal starch gel electrophoresis (Selander et al., 1971). For the preparation of the buffers used for the assay, see Noy et al. (1987). The alleles were recorded according to their place on the electrophoretic gel: $F$ was the fastest (most anodal) and $\mathrm{S}^{-}$was the slowest allele. The $P G I$ locus in both species had 3 alleles (S, M, F); the AP locus had 5 alleles $\left(\mathrm{S}^{-}, \mathrm{SMM}^{+}, \mathrm{F}\right)$. As the electrophoretic analysis is much more expensive and time consuming than the viability survey, only part of the participants in these experiments were analyzed electrophoretically (Table I, II).

\section{RESULTS}

Table I summarizes all the data obtained on allozyme frequencies under treatment with nonionic detergent and crude oil-detergent mixtures in aqueous solutions at the PGI locus, for Littorina punctata. When the pollutant used was the nonionic detergent by itself, selection acted against the genotype FF and the allele $F$ in general and favored the genotype MM. The fact that the statistical results also show a higher frequency of the allele $M$ among the live animals than among the dead, is a consequence of the huge proportion of the genotype MM among the live animals; other $\mathrm{M}$ bearing genotypes were not favoured.

When the pollutant used was crude oil and non-ionic detergent mixture, a reversion in the viability fitness could be observed: In general, the FF genotype and $F$ allele were favoured by the selection which acted against the SS genotype and the $\mathrm{S}$ allele.

Table II summarizes all the data obtained on allozyme frequencies under treatment with nonionic detergent and crude oil-detergent mixtures in aqueous solutions at the PGI and AP loci for Littorina neritoides. The trends were similar in both types of pollution, but more accentuated in the combined pollution. Heterozygotes, in general, showed higher fitness viability (especially FM in the $P G I$ system in oil pollution. In the $A P$ system, the $\mathrm{FM}^{+}$in detergent pollution and $\mathrm{M}^{+} \mathrm{S}$ in oil pollution). Considering homozygotic genotypes, the detergent applied by itself favoured the FF genotype of $P G I$, and the combined pollution acted against the MM genotype of $P G I$ and against the MM and SS genotypes of $A P$. 
Table I. Differential survivorship of $P G I$ allozyme genotypes of Littorina punctata in nonionic detergent and crude oil-surfactant mixtures.

\begin{tabular}{|c|c|c|c|c|c|c|c|}
\hline \multirow{4}{*}{$\begin{array}{l}\text { Pollutant } \\
\text { Pollutant concentration } \mathrm{mg} / \mathrm{l} \\
\text { No. of test } \\
\text { Animals tested }\end{array}$} & & \multicolumn{3}{|c|}{ Nonionic detergent } & \multicolumn{3}{|c|}{$\begin{array}{l}\text { Crude oil and nonionic } \\
\text { detergent }(7 \mathrm{mg} / \mathrm{l})\end{array}$} \\
\hline & & $7-117$ & & & $7-32$ & & \\
\hline & & 6 & & & 6 & & \\
\hline & & Live & Dead & Significance & Live & Dead & Significance \\
\hline in pollution experiments & & 126 & 311 & & 99 & 284 & \\
\hline analyzed electrophoretically & & 72 & 68 & & 72 & 70 & \\
\hline \multirow[t]{6}{*}{ Genotypes } & MM & 0.722 & 0.485 & $* *$ & 0.680 & 0.742 & \\
\hline & $\mathrm{FF}$ & 0.097 & 0.294 & $* *$ & 0.097 & 0.000 & $* *$ \\
\hline & SS & 0.042 & 0.029 & & 0.000 & 0.086 & $* *$ \\
\hline & FM & 0.083 & 0.089 & & 0.139 & 0.029 & $* *$ \\
\hline & FS & 0.000 & 0.029 & & 0.042 & 0.029 & \\
\hline & MS & 0.056 & 0.074 & & 0.042 & 0.114 & \\
\hline Observed heterozygosity & & 0.139 & 0.192 & & 0.223 & 0.172 & \\
\hline \multirow[t]{3}{*}{ Alleles } & $M$ & 0.792 & 0.566 & $* *$ & 0.770 & 0.813 & \\
\hline & $\mathrm{F}$ & 0.138 & 0.353 & $* *$ & 0.188 & 0.029 & $* * *$ \\
\hline & $\mathrm{S}$ & 0.070 & 0.081 & & 0.042 & 0.158 & $* *$ \\
\hline
\end{tabular}

** $=P<0.01$ (by test for proportions; Bailey, 1959)

*** $=P<0.001$ (by test for proportions; Bailey, 1959)

Notably, while the trend of higher frequency of heterozygotes among the survivors of oil pollution was not significant for Littorina punctata alone, the combined probabilities for both species was $\mathrm{P}<0.001 ; \chi_{6}^{2}=25.4346$ (Sokal \& Rohlf, 1969).

\section{DISCUSSION}

The effects of detergents on the marine biota were reported by several studies: Manwell \& Baker (1967) performed starch gel electrophoresis on a variety of enzymes and other proteins that had been exposed to detergent pollution. They worked on in vitro tissues, so they were unable to observe the differential survivorship of various genotypes. They discussed only the general influence of detergent on solubility, activity and electrophoretic mobility of proteins. The in vivo effects of detergents on the marine biota were reported in several studies; on the chemical senses of fish (Bardach et al., 1965) on marine gastropods (Bryan, 1969) and on crustacea (Kaim-Malka, 1972). But these studies did not deal with the influence of detergent pollution on the genetic patterns of allozyme polymorphisms.

Oil pollution of the sea has received a great deal of attention from research workers throughout the world, especially due to disasters of giant oil tankers in the oceans. Certain constituents of oil, particularly the aromatic hydrocarbons, can 
Table II. Differential survivorship of $P G I$ and $A P$ allozyme genotypes of Littorina neritoides in nonionic detergent and crude oil-surfactant mixtures.

\begin{tabular}{|c|c|c|c|c|c|c|c|}
\hline \multicolumn{2}{|l|}{ Pollutant } & \multicolumn{3}{|c|}{ Nonionic detergent } & \multicolumn{3}{|c|}{$\begin{array}{l}\text { Crude oil and nonionic } \\
\text { detergent }(7 \mathrm{mg} / \mathrm{l})\end{array}$} \\
\hline \multicolumn{2}{|l|}{ Pollutant concentration $\mathrm{mg} / \mathrm{l}$} & $7-117$ & & & $7-32$ & & \\
\hline \multicolumn{2}{|l|}{ No. of test } & 6 & & & 6 & & \\
\hline \multicolumn{2}{|l|}{ Animals tested } & Live & Dead & Significance & Live & Dead & Significance \\
\hline \multirow{3}{*}{\multicolumn{2}{|c|}{$\begin{array}{l}\text { in pollution experiments } \\
\text { analyzed electrophoretically }\end{array}$}} & 167 & 310 & & 128 & 284 & \\
\hline & & $P G I A P$ & $P G I A P$ & & $P G I A P$ & $P G I A P$ & \\
\hline & & 6965 & $59 \quad 59$ & & $72 \quad 60$ & $60 \quad 55$ & \\
\hline \multicolumn{8}{|l|}{$P G I$} \\
\hline \multirow[t]{6}{*}{ Genotypes } & MM & 0.493 & 0.661 & & 0.653 & 0.817 & $*$ \\
\hline & FF & 0.145 & 0.051 & $\$$ & 0.083 & 0.083 & \\
\hline & SS & 0.043 & 0.068 & & 0.042 & 0.017 & \\
\hline & FM & 0.174 & 0.101 & & 0.167 & 0.050 & * \\
\hline & FS & 0.014 & 0.034 & & 0.000 & 0.000 & \\
\hline & MS & 0.131 & 0.085 & & 0.055 & 0.033 & \\
\hline Observed heterozygosity & & 0.319 & 0.203 & & 0.222 & 0.083 & $*$ \\
\hline \multirow[t]{3}{*}{ Alleles } & M & 0.645 & 0.754 & & 0.764 & 0.858 & \\
\hline & $\mathrm{F}$ & 0.239 & 0.118 & & 0.167 & 0.108 & \\
\hline & $\mathrm{S}$ & 0.116 & 0.128 & & 0.069 & 0.034 & \\
\hline \multicolumn{8}{|l|}{$A P$} \\
\hline \multirow[t]{11}{*}{ Genotypes } & $\mathrm{MM}$ & 0.169 & 0.220 & & 0.042 & 0.182 & $*$ \\
\hline & $\mathrm{FF}$ & 0.015 & 0.051 & & 0.014 & 0.018 & \\
\hline & $\mathrm{M}+\mathrm{M}+$ & 0.046 & 0.152 & & 0.028 & 0.036 & \\
\hline & SS & 0.031 & 0.085 & & 0.042 & 0.127 & $*$ \\
\hline & FM & 0.123 & 0.068 & & 0.097 & 0.091 & \\
\hline & $\mathrm{FM}+$ & 0.077 & 0.000 & $*$ & 0.000 & 0.000 & \\
\hline & FS & 0.200 & 0.102 & & 0.055 & 0.055 & \\
\hline & $M+M$ & 0.200 & 0.085 & & 0.292 & 0.273 & \\
\hline & $M+S$ & 0.108 & 0.169 & & 0.333 & 0.163 & $*$ \\
\hline & $\mathrm{M}+\mathrm{S}-$ & 0.015 & 0.000 & & 0.042 & 0.000 & \\
\hline & MS & 0.015 & 0.068 & & 0.055 & 0.055 & \\
\hline Observed heterozygosity & & 0.738 & 0.492 & $* *$ & 0.874 & 0.637 & $* * *$ \\
\hline \multirow[t]{5}{*}{ Alleles } & $\mathrm{M}$ & 0.338 & 0.330 & & 0.264 & 0.392 & \\
\hline & $F$ & 0.215 & 0.136 & & 0.090 & 0.091 & \\
\hline & $\mathrm{M}+$ & 0.246 & 0.279 & & 0.362 & 0.254 & \\
\hline & $\mathrm{S}$ & 0.193 & 0.255 & & 0.263 & 0.263 & \\
\hline & S- & 0.008 & 0.000 & & 0.021 & 0.000 & \\
\hline
\end{tabular}

$\$ P<0.05$ (by sign test; Siegel, 1956)

* $P<0.05$ (by test for proportions; Bailey, 1959)

** $P<0.01$ (by test for proportions; Bailey, 1959)

*** $P<0.001$ (by test for proportions; Bailey, 1959) 
be shown in laboratory experiments to be harmful to marine organisms. Effects of oil pollution on coral reef communities has been critically reviewed by Loya $\&$ Rinkevitch (1980). They reported a syndrome of oil effects, including complete lack of colonization by hermatypic corals in reef areas chronically polluted by oil, decrease in colony viability, damage to the reproductive systems of corals, lower life expectancy of planulae, and abnormal behavioral responses of planulae and corals. For the herring gull chick (Larus argentatus), Miller et al. (1978) reported that a single small oral dose of Kuwait or South Louisiana crude oil, caused cessation of growth, osmoregulatory impairment, and hypertrophy of hepatic adrenal and nasal gland tissue. The biological effects of oil pollution on littoral communities were described by Beer (1968), and the acute toxicities of crude oils and oil dispersant mixtures on marine fish and inverterbrates were reported by Eisler (1975).

A post hoc approach to the problem of selection pressure on specific genotypes of marine organisms by oil pollution was reported by Battaglia et al. (1980), who compared the genotypic pattern of Tisbe holothuriae and Mytilus galloprovincialis at sites with various degrees of oil pollution. They found significant differences in viability, especially for genotypes of the locus $P G I$. In an early study with detergent and with crude oil-detergent pollution, we have found in laboratory controlled experiments, differential viability of $P G I$ genotypes of the marine gastropods Monodonta turbinata and $M$. turbiformis (Lavie et al., 1984) and of six loci tested in the marine gastropod Cerithium scabridum, either singly or in a two-locus genetic structure (Nevo \& Lavie, 1989).

The present study reports the selective nature of the genotypes in an a priori designed experiment, with precise concentrations of specific pollutants, avoiding any effects of additional unknown pollutants. The pollutant concentration needed in order to obtain $\mathrm{LD}_{50}$ was, in all cases, much higher than its concentration, even in the polluted sea environment. Yet, while pollution effects may be small in open sea situations, effects are certainly appreciable locally in estuaries and coastal waters. The laboratory experiments considered only survivorship because they involved species that do not reproduce successfully in laboratory conditions. Yet, in nature, tolerant genotypes may not only live longer, but presumably also reproduce successfully in the polluted environment.

Like Battaglia et al. (1980), we found that oil pollution favoured the heterozygotes. As in our previous studies on detergent and oil pollution (Lavie et al., 1984; Nevo et al., 1988), we found for $L$. neritoides, similar trends in detergent pollution by itself and in the pollution by oil-surfactant mixtures. This may have been influenced by the fact that the surfactant used in the oil-surfactant mixtures, was the detergent in case. Yet for L. punctata, the synergism of the two pollutants produced results completely opposed to the pollution by detergent alone. This is in good accord with our previous experiments on the synergetic effects of pollutants (cadmium and mercury pollution). We found that the combined pollution had a unique influence on the distribution of allozyme frequences for Cerithium scabridum (Lavie \& Nevo, 1988); for L. punctata and L. neritoides (Lavie \& Nevo, 1987), and for Palaemon elegans (Ben-Shlomo \& Nevo, 1988). The biochemical mechanisms involved in differential viability, and the specific targets of selection need future elucidation. 
We conclude that the present study supports previous ones (reviewed in Nevo, 1986), suggesting that at least some allozyme polymorphisms are subject to natural selection. Actually, during our research program in controlled environments (10 types of pollutants and six species of marine organisms), only a single case of no differential survivorship due to pollution could be detected (e.g. in Monodonta turbiformis in zinc pollution) [Nevo et al., 1983]. The sensitivity of change in allele frequencies of allozymes to environmental stress makes them appropriate as genetic detectors and monitors of organic pollutants. Such direct genetic indicators can complement other methods of bio- and chemical monitoring. The merit of genetic monitoring is that it alerts us to both the short-and long-term genetic changes that populations undergo, before their extermination resulting from environmental stress pollution.

\section{ACKNOWLEDGEMENTS}

We thank Shimon Simson for field and laboratory assistance, and wish to extend our deep gratitude for financial support, to FAO/UNEP, to the Israel Discount Bank Chair of Evolutionary Biology and to the Ancell-Teicher Research Foundation for Genetics and Molecular Evolution, established by Florence and Theodore Baumritter of New York.

\section{REFERENCES}

Bailey N.T.J. (1959) Statistical Methods in Biology. English University Press, London, pp. 38-39

Bardach J.E., Fujiya M. \& Holt A. (1965) Detergents: Effects on the chemical senses of the fish Tetalrus natilis (le Suer). Science 148, 1605-1607

Battaglia B., Bisol P.M. \& Rodino E. (1980) Experimental studies on some genetic effects of marine pollution. Helgol. Wiss. Meeresunters. 33, 587-595

Beer J.V. (1968) In: The Biological Effects of Oil Pollution on Littoral Communities (J.C. Carthy \& D.R. Arthur eds), Field Studies Council London, 123

Ben-Shlomo R. \& Nevo E. (1988) Isozyme polymorphism as monitoring of marine environments: The interactive effect of cadmium and mercury pollution on the shrimp Palaemon elegans. Mar. Pollut. Bull. 19, 314-317

Bryan G.W. (1969) The effects of oil spill removers (detergents) on the gastropod Nucella lapellus on a rocky shore and in the laboratory. J. Mar. Biol. Assoc. U.K. 49, 1067-1092

Eisler R. (1975) Acute toxicities of crude oils and oil-dispersant mixtures to Red Sea fishes and inverterbrates. Isr. J. Zool. 24, 16-27

Frankel O.H. \& Soule M. (1981) Conservation and Evolution, Cambridge Univ. Press, London/New York

Kaim-Malka R.A. (1972) Action des détergents sur deux espèces de Crustacés (Action of detergents on two species of crustacea). Rapp. P.V. Réun. Cons. Int. Explor. Mer. 21, 255-258

Lavie B. \& Nevo E. (1987) Differential fitness of allelic isozymes in the marine gastropods. Littorina punctata and Littorina neritoides exposed to the environmental 
stress of the combined effects of cadmium and mercury pollution. Environ. Man 11, 345-349

Lavie B. \& Nevo E. (1988) Multilocus genetic resistance and susceptibility to mercury and cadmium pollution in the marine gastropod Cerithium scabridum. Aquat. Toxicol 13, 291-296

Lavie B., Nevo E. \& Zoller U. (1984) Differential viability of phosphoglucose isomerase allozyme genotypes of marine snails in nonionic detergent and crude oil-surfactant mixtures. Environ. Res. 35, 270-276

Loya Y. \& Rinkevich B. (1980) Effects of oil pollution on coral reef communities. Mar. Ecol. Prog. Ser. 3, 167-180

Manwell C. \& Baker C.M.A. (1967) A study of detergent pollution by molecular methods: Starch gel electrophoresis of a variety of enzymes and other proteins. $J$. Mar. Biol. Assoc. U.K. 47, 659-675

Miller D.S., Peakall D.B. \& Kinter W.B. (1978) Ingestion of crude oil: Sublethal effects in herring gull chicks. Science 199, 315-317

Nevo E. (1986) Pollution and genetic evolution in marine organisms: Theory and practice. In: Environmental Quality and Ecosystem Stability (Z. Dubinsky \& Y. Steinberger eds) Bar Ilan Univ. Press, Ramat-Gan, Israel, Vol 3 A/B, pp. 841-848 Nevo E. \& Lavie B. (1989) Differential viability fitness of allelic isozymes in the marine gastropod Cerithium scabridum exposed to the environmental stress of nonionic detergent and crude oil-surfactant mixtures. Genetica (in press)

Nevo E., Golenberg E., Brown A.H.D., Beiles A. \& Zohary D. (1982) Genetic diversity and environmental associations of wild wheat Triticum dicoccoides, in Israel. Theor. Appl. Genet. 62, 241-254

Nevo E., Lavie B. \& Ben-Shlomo R. (1983) Selection of allelic isozyme polymorphisms in marine organisms: Pattern, theory and application. In: Isozymes: Current Topics in Biological and Medical Research. (Rattazi M.C., Scandalios J.G. \& Whill G.S. eds) Alan R. Liss, Inc., New York, 30, pp. 69-92

Nevo E., Lavie B. \& Ben-Shlomo R. (1988) Population genetic structure of marine organisms as detectors and monitors of marine pollution, FAO/UNEP. Scient. Reports 24, 37-49

Noy R., Lavie B. \& Nevo E. (1987) The niche-width variation hypothesis revisited: Genetic diversity in the marine gastropods Littorina punctata (Gmelin) and $L$. neritoides (L). J. Exp. Mar. Biol. Ecol. 109, 109-116

Palant B. \& Fishelson L. (1968) Littorina punctata (Gmelin) and Littorina neritoides (L) (Mollusca, Gastropoda) from Israel: Ecology and annual cycle of genital system. Isr. J. Zool. 17, 145-160

Schonewald-Cox C.M., Chambers S.M., MacBryde B. \& Thomas L. (1983) Genetics and Conservations. The Benjamin Cummings Pub. Co., Inc., London

Selander R., Smith M.H., Young S.Y., Johnson E.W. \& Gentry G.B. (1971) Biochemical polymorphism and systematics in the genus Peromyscus. I. Variation in the old field mouse (Peromyscus polionotus). Univ. Tex. Publ. 7 103, 49-90

Siegel S. (1956) Nonparametric Statistics for the Behavioral Sciences. Academic Press, New York

Sokal R. R. \& Rohlf F. J. (1969) Biometry. Freeman, San Francisco Soule E. (ed.) (1987) Viable Populations for Conservation. Cambridge University Press, Cambridge, New York 